\title{
Biosorption of lead(II), zinc(II) and nickel(II) from industrial wastewater by Stenotrophomonas maltophilia and Bacillus subtilis
}

\author{
Sławomir Wierzba \\ Opole University, Chair of Biotechnology and Molecular Biology, ul. Kardynata Kominka 6a, 40-035 Opole \\ e-mail: slawomirwierzba@uni.opole.pl
}

\begin{abstract}
The biosorption of $\mathrm{Pb}(\mathrm{II}), \mathrm{Zn}(\mathrm{II})$ and $\mathrm{Ni}(\mathrm{II})$ from industrial wastewater using Stenotrophomonas maltophilia and Bacillus subtilis was investigated under various experimental conditions regarding $\mathrm{pH}$, metal concentration and contact time. The optimum $\mathrm{pH}$ values for the biosorption of the three metals were in the range 5.0-6.0, while the optimal contact time for the two bacterial species was $30 \mathrm{~min}$. Experimental data was analyzed using Langmuir and Freundlich isotherms; the former had a better fit for the biosorption of $\mathrm{Pb}(\mathrm{II}), \mathrm{Zn}(\mathrm{II})$ and $\mathrm{Ni}(\mathrm{II})$. The maximum adsorption uptakes $\left(\mathrm{q}_{\max }\right)$ of the three metals calculated from the Langmuir biosorption equation for S. maltophilia were 133.3, 47.8 and 54.3 for $\mathrm{Pb}(\mathrm{II}), \mathrm{Zn}$ (II) and $\mathrm{Ni}(\mathrm{II})$, respectively, and for $B$. subtilis were 166.7, 49.7 and $57.8 \mathrm{mg} / \mathrm{g}$, respectively. B. subtilis biomass was more favorable for the biosorption of $\mathrm{Pb}$ (II) and $\mathrm{Ni}$ (II), while S. maltophilia was more useful for the biosorption of $\mathrm{Zn}$ (II).
\end{abstract}

Keywords: heavy metals, biosorption, Bacillus subtilis, Stenotrophomonas maltophilia.

\section{INTRODUCTION}

Pollution of the environment with toxic heavy metals is spreading throughout the world alongside industrial expansion; the resultant contamination of soils, groundwater, sediments, surface water and the air poses significant problems for both human health and the environment ${ }^{1}$. Despite serious environmental concerns due to their toxicity even at low concentrations ${ }^{1-5}$, various industrial processes, such as electroplating, metal finishing, metallurgical work, tanning, chemical manufacturing, mining and battery manufacturing, result in the continuous introduction of heavy metal polluted wastewater to the environment (mainly $\mathrm{Pb}, \mathrm{Hg}, \mathrm{Cu}, \mathrm{Cd}, \mathrm{Zn}, \mathrm{Ni}$ and $\mathrm{Cr}$ ).

With regard to their impact on human health, each heavy metal imparts different effects and symptoms. For instance, in the case of minor $\mathrm{Zn}$ exposure, common symptoms are irritability, muscular stiffness, loss of appetite and nausea ${ }^{6,7}$. $\mathrm{Pb}$ is extremely toxic and can inflict damage to the nervous system, kidneys and reproductive system, particularly in children ${ }^{4,7}$. The presence of $\mathrm{Ni}$ above a critical level might bring about serious lung and kidney problems, aside from gastrointestinal distress, pulmonary fibrosis and skin dermatitis ${ }^{8}$.

Conventional methods used to remove dissolved heavy metal ions from wastewaters include chemical precipitation, chemical oxidation or reduction, ion exchange, filtration, electrochemical treatment, solvent extraction, reverse osmosis, membrane technologies and evaporation recovery. These processes may be ineffective or extremely expensive, especially when the metals in solution are in the range $1-100 \mathrm{mg} / \mathrm{l}^{\mathbf{8}, 9}$. Another major disadvantage of conventional treatment methods is the production of toxic chemical sludge and its subsequent disposal/ treatment being costly and not eco-friendly. Therefore, it is so significant to find a cost effective and environment-friendly method of removing toxic heavy metals down to a level considered environmentally safe ${ }^{\mathbf{4}, 10}$.

One of the most promising technologies involved in the removal of toxic metals from industrial waste streams is biosorption, based on the ability of many algae, fungi, yeasts and bacteria to concentrate heavy metals from aquatic environments ${ }^{\mathbf{8}, 11,12}$. It offers the advantages of low operating costs, the possibility of metal recovery, regeneration of the biosorbent, minimization of the volume of chemical and/or biological sludge to be disposed of, and high efficiency in detoxifying very dilute effluents ${ }^{13-15}$. This complex process depends on the properties of metal ions, the cell wall composition of microorganisms, cell physiology, as well as physicochemical factors such as $\mathrm{pH}$, temperature, contact time, ionic strength, and metal concentration $^{15}$. It occurs through complexation, coordination, physical adsorption, chelation, ion exchange, inorganic precipitation or some combination of these processes ${ }^{11,16}$. These processes involve the active participation of several anionic ligands present in the biomass, such as phosphoryl, carboxyl, carbonyl, sulfydryl and hydroxyl groups, to immobilize metal ions ${ }^{17}$.

The main objective of this work was to study differences in the adsorption of $\mathrm{Pb}(\mathrm{II}), \mathrm{Zn}$ (II) and $\mathrm{Ni}(\mathrm{II})$ between Stenotrophomonas maltophilia and Bacillus subtilis cells isolated from a wastewater treatment plant. Factors affecting biosorption (i.e. $\mathrm{pH}$, reaction duration, metal concentration) were also studied. Biosorption isotherms and kinetics were determined from biosorption measurements.

\section{EXPERIMENTAL}

\section{Microorganisms}

Lead, zinc and nickel resistant bacterial strains were isolated from a wastewater treatment plant located in Głubczyce (Poland). Samples were diluted 10-10.000 fold in sterile distilled water and plated on Nutrient Agar (Merck). To isolate resistant strains, the media were amended with $100 \mathrm{mg} / \mathrm{l} \mathrm{Pb}$ (II), $50 \mathrm{mg} / \mathrm{l} \mathrm{Zn(II)} \mathrm{and}$ $50 \mathrm{mg} / \mathrm{l} \mathrm{Ni(II)}$ and a standard spread plate method was performed. The inoculated plates were incubated for $48 \mathrm{~h}$ at $30^{\circ} \mathrm{C}$ after which larger identical colonies from each plate were isolated. The most effective bacterial strains for the biosorption of $\mathrm{Pb}(\mathrm{II})$ and $\mathrm{Ni}(\mathrm{II})$ were identified according to Bergey's Manual of Systematic Bacteriology ${ }^{18}$. Morphological, physiological and biochemical characteristics of the isolated bacterial species (S. maltophilia and B. subtilis) are given in Table 1. 
Table 1. Biochemical characterization of the isolate strains

\begin{tabular}{|c|c|c|c|}
\hline & Result & Properties & Result \\
\hline Gram reaction & + & Gram reaction & - \\
\hline Cell shape & Rod & Cell shape & Rod \\
\hline Cell diameter $>1.0 \mu \mathrm{m}$ & - & Motility & + \\
\hline Spores round & + & Catalase test & + \\
\hline Catalase & + & Citrate test & + \\
\hline Oxygen requirements & Aerobic & Oxidase test & - \\
\hline Voges-Proskauer test & + & Methyl red test & - \\
\hline Glucose & + & Voges-Proskauer test & - \\
\hline Xylose & + & Gelatin test & + \\
\hline Mannitol & + & Starch test & - \\
\hline Hydrolysis of casein & + & Arabinose & - \\
\hline Hydrolysis of gelatin & + & Dextrose & + \\
\hline Hydrolysis of starch & + & Fructose & - \\
\hline Utilization of citrate & + & Galactose & - \\
\hline Nitrate reduced to nitrite & + & Inositol & - \\
\hline Formation of indole & - & Lactose & - \\
\hline Growth at $\mathrm{pH} 6.8$, nutrient broth & + & Maltose & + \\
\hline Growth at $\mathrm{pH} 5.7$, nutrient broth & + & Mannitol & - \\
\hline Growth in $\mathrm{NaCl} 2 \%$ & + & Mannose & - \\
\hline Growth in $\mathrm{NaCl} 5 \%$ & ND & Sorbitol & - \\
\hline Growth in $\mathrm{NaCl} 7 \%$ & - & Sucrose & + \\
\hline Growth in $\mathrm{NaCl} 10 \%$ & ND & Trehalose & + \\
\hline Growth at $5^{\circ} \mathrm{C}$ & + & Xylose & - \\
\hline Growth at $10^{\circ} \mathrm{C}$ & + & Nitrate reduction & + \\
\hline Growth at $30^{\circ} \mathrm{C}$ & ND & Type strain & - \\
\hline Growth at $40^{\circ} \mathrm{C}$ & - & & Stentrophomonas maltophilia \\
\hline Growth at $50^{\circ} \mathrm{C}$ & - & & \\
\hline Growth at $55^{\circ} \mathrm{C}$ & - & & \\
\hline Growth at $65^{\circ} \mathrm{C}$ & - & & \\
\hline Type strain & Bacillus subtilis & & \\
\hline
\end{tabular}

\section{Preparation of biomass}

Bacterial strains of $S$. maltophilia and B. subtilis were cultivated aerobically at $30^{\circ} \mathrm{C}$ in Nutrient Broth (Merck) constantly agitated at $150 \mathrm{rpm}$ in glass flasks. After inoculation, cells were harvested by means of centrifugation for $20 \mathrm{~min}$ at $3000 \mathrm{rpm}$. The cell pellet was rinsed three times with sterile deionized water, then freeze dried using a lyophilizer (Alpha 1-2 LD plus, Christ, Germany). For the purpose of the biosorption experiments, $1 \mathrm{~g}$ portions of bacterial cell mass (separately for S. maltophilia and B. subtilis) were suspended in 11 of deionized water.

\section{Wastewater sample}

Wastewater was obtained from a chemical manufacturing plant in Głubczyce (Poland). The composition of the wastewater is given in Table 2. The concentrations of the other metal ions present in the wastewater were so minimal that they would not effect the removal of lead, zinc and nickel ions from the wastewater. If necessary, the effluent was diluted with deionized water to an appropriate concentration of heavy metals.

Table 2. Characteristics of wastewater used

\begin{tabular}{|l|c|}
\hline Characteristics & Value \\
\hline $\mathrm{pH}$ & $2.5-5.3$ \\
\hline Lead $[\mathrm{mg} / \mathrm{l}]$ & 326.4 \\
Zinc $[\mathrm{mg} / \mathrm{l}]$ & 178.2 \\
Nickel $[\mathrm{mg} / \mathrm{l}]$ & 249.3 \\
Cadmium [mg/l] & 0.1 \\
Cobalt $[\mathrm{mg} / \mathrm{l}]$ & 0.1 \\
Copper $[\mathrm{mg} / \mathrm{l}]$ & 0.2 \\
\hline
\end{tabular}

\section{Heavy metal assay}

The concentrations of $\mathrm{Pb}(\mathrm{II}), \mathrm{Zn}$ (II) and $\mathrm{Ni}$ (II) in the biosorption experiments were determined spectrophotometrically (Photolab Spectral, WTW, Germany). Before measuring the samples were passed through a
Whatman filter (pore size $0.45 \mu \mathrm{m}$ ) and then diluted with deionized water. The initial and the final concentrations of heavy metals used in batch mode studies were estimated spectrophotometrically. The removal efficiency of the microorganisms was calculated from the difference between initial and final concentrations.

\section{Biosorption experiments}

Parameters of $\mathrm{Pb}(\mathrm{II}), \mathrm{Zn}(\mathrm{II})$ and $\mathrm{Ni}(\mathrm{II})$ sorption by S. maltophilia and B. subtilis are presented in Table 3.

Experimental tests were conducted in a BIOSTAT A-plus bioreactor containing 1.01 of wastewater at constant level of biomass $(1.0 \mathrm{~g} / \mathrm{l})$ at $30^{\circ} \mathrm{C}$ and agitation of $200 \mathrm{rpm}$. Biosorption experiments were carried out to investigate the effects of $\mathrm{pH}$, contact duration and initial metal concentration. The $\mathrm{pH}$ values were adjusted between $2.0-7.0$ by adding $0.1 \mathrm{M} \mathrm{NaOH}$ or $0.1 \mathrm{M} \mathrm{HNO}_{3}$. The contact durations ranged from $0-60 \mathrm{~min}$. The initial $\mathrm{Pb}(\mathrm{II}), \mathrm{Zn}(\mathrm{II})$ and $\mathrm{Ni}(\mathrm{II})$ concentrations varied from 15.9 to $325.3 \mathrm{mg} / \mathrm{l}, 11.2$ to $172.3 \mathrm{mg} / \mathrm{l}$ and 14.3 to $245.8 \mathrm{mg} / \mathrm{l}$, respectively. The metal uptake (mg metal/g dry biomass) was calculated according to:

$$
q_{e}=\frac{\left(C_{0}-C_{e}\right) V}{M}
$$

Where $C_{0}$ and $C_{e}$ are the respective initial and equilibrium metal concentrations in the solution $(\mathrm{mg} / \mathrm{l}), V$ is the volume of the solution (1), and $M$ is the dry weight of the biomass $(\mathrm{g})$. The metal sorption ability of the biomass was determined by the above-mentioned procedure in all the following experiments unless stated otherwise.

\section{Adsorption isotherms}

Heavy metals biosorption isotherms were obtained at constant $\mathrm{pH}$ and ionic strength. To test the fit of data, Langmuir and Freundlich isotherm models were applied 
Table 3. Parameters characterizing biosorption experiments

\begin{tabular}{|c|c|c|c|c|c|c|c|c|}
\hline \multirow[b]{2}{*}{$\begin{array}{l}\text { Biosorption } \\
\text { experiments }\end{array}$} & \multirow{2}{*}{$\begin{array}{c}\text { Biosorbent } \\
\text { dose } \\
{[\mathrm{mg} / \mathrm{l}]}\end{array}$} & \multirow[b]{2}{*}{$\begin{array}{c}\text { Temperature } \\
{\left[{ }^{\circ} \mathrm{C}\right]}\end{array}$} & \multirow{2}{*}{$\begin{array}{l}\text { Agitation } \\
\text { speed } \\
\text { [rpm] }\end{array}$} & \multirow[b]{2}{*}{$\mathrm{pH}$} & \multirow[b]{2}{*}{$\begin{array}{c}\text { Time } \\
\text { [minute] }\end{array}$} & \multicolumn{3}{|c|}{ Heavy metal concentration } \\
\hline & & & & & & $\begin{array}{l}\mathrm{Pb}(\mathrm{II}) \\
{[\mathrm{mg} / \mathrm{l}]}\end{array}$ & $\begin{array}{l}\mathrm{Zn}(\mathrm{II}) \\
{[\mathrm{mg} / \mathrm{l}]}\end{array}$ & $\begin{array}{l}\mathrm{Ni}(\mathrm{II}) \\
{[\mathrm{mg} / \mathrm{ll}]}\end{array}$ \\
\hline \multirow{6}{*}{ Effect of $\mathrm{pH}$} & 1.0 & 30 & 200 & 2 & 30 & 98.4 & 39.6 & 45.6 \\
\hline & 1.0 & 30 & 200 & 3 & 30 & 98.4 & 39.6 & 45.6 \\
\hline & 1.0 & 30 & 200 & 4 & 30 & 98.4 & 39.6 & 45.6 \\
\hline & 1.0 & 30 & 200 & 5 & 30 & 98.4 & 39.6 & 45.6 \\
\hline & 1.0 & 30 & 200 & 6 & 30 & 98.4 & 39.6 & 45.6 \\
\hline & 1.0 & 30 & 200 & 7 & 30 & 98.4 & 39.6 & 45.6 \\
\hline \multirow{12}{*}{$\begin{array}{l}\text { Effect of contact } \\
\text { time }\end{array}$} & 1.0 & 30 & 200 & 5.5 & 5 & 98.4 & 39.6 & 45.6 \\
\hline & 1.0 & 30 & 200 & 5.5 & 10 & 98.4 & 39.6 & 45.6 \\
\hline & 1.0 & 30 & 200 & 5.5 & 15 & 98.4 & 39.6 & 45.6 \\
\hline & 1.0 & 30 & 200 & 5.5 & 20 & 98.4 & 39.6 & 45.6 \\
\hline & 1.0 & 30 & 200 & 5.5 & 25 & 98.4 & 39.6 & 45.6 \\
\hline & 1.0 & 30 & 200 & 5.5 & 30 & 98.4 & 39.6 & 45.6 \\
\hline & 1.0 & 30 & 200 & 5.5 & 35 & 98.4 & 39.6 & 45.6 \\
\hline & 1.0 & 30 & 200 & 5.5 & 40 & 98.4 & 39.6 & 45.6 \\
\hline & 1.0 & 30 & 200 & 5.5 & 45 & 98.4 & 39.6 & 45.6 \\
\hline & 1.0 & 30 & 200 & 5.5 & 50 & 98.4 & 39.6 & 45.6 \\
\hline & 1.0 & 30 & 200 & 5.5 & 55 & 98.4 & 39.6 & 45.6 \\
\hline & 1.0 & 30 & 200 & 5.5 & 60 & 98.4 & 39.6 & 45.6 \\
\hline \multirow{9}{*}{$\begin{array}{c}\text { Effect of heavy } \\
\text { metal concentration }\end{array}$} & 1.0 & 30 & 200 & 5.5 & 30 & 15.9 & 11.2 & 14.3 \\
\hline & 1.0 & 30 & 200 & 5.5 & 30 & 39.6 & 20.6 & 31.5 \\
\hline & 1.0 & 30 & 200 & 5.5 & 30 & 81.5 & 42.3 & 60.2 \\
\hline & 1.0 & 30 & 200 & 5.5 & 30 & 125.4 & 62.4 & 90.2 \\
\hline & 1.0 & 30 & 200 & 5.5 & 30 & 147.8 & 86.0 & 123.6 \\
\hline & 1.0 & 30 & 200 & 5.5 & 30 & 162.7 & 104.3 & 159.4 \\
\hline & 1.0 & 30 & 200 & 5.5 & 30 & 201.3 & 132.2 & 188.6 \\
\hline & 1.0 & 30 & 200 & 5.5 & 30 & 250.6 & 149.9 & 221.4 \\
\hline & 1.0 & 30 & 200 & 5.5 & 30 & 325.3 & 172.3 & 245.8 \\
\hline
\end{tabular}

to this study. The Langmuir isotherm model is valid for monolayer sorption onto a surface and a finite number of identical sites, and is given by:

$q_{e q}=\frac{q_{\max } b C_{e q}}{1+b C_{e q}}$

or presented in linear form as follows:

$\frac{1}{q_{e q}}=\frac{1}{q_{\max }}+\frac{1}{b q_{\max } C_{e q}}$

Where $q_{\max }$ is the maximum amount of the metal ion per unit weight of the cell to form a complete monolayer on the surface bound at a high $C_{e q}(\mathrm{mg} / \mathrm{l})$ and $b$, a constant related to the affinity of the binding sites, $q_{\max }$ represents a practical limiting adsorption capacity when the surface is fully covered with metal ions and assists in the comparison of adsorption performance, particularly in cases where the sorbent did not reach full saturation in experiments. Another essential factor of the Langmuir isotherm is $R_{L}$, which can be calculated according to the following equation:

$R_{L}=\frac{1}{1+b C_{o}}$

Where $C_{0}$ is the highest metal concentration $(\mathrm{mg} / \mathrm{l})$.

The empirical Freundlich isotherm model based on a heterogeneous surface is given by:

$q_{e q}=K_{f} \cdot C_{e q}^{l / n}$

Where $K_{f}$ and $n$ are Freundlich constants characteristic of the system, $K_{f}$ and $n$ are indicators of adsorption capacity and intensity, respectively. Freundlich parameters can be determined from the linear form of the eq. (5) by plotting the $\ln q_{e q}$ versus $\ln C_{e q}$ the slope is the value of $1 / n$ and the intercept is equal to $\ln K_{f}$. The Freundlich isotherm is also more widely used and provides information on the monolayer adsorption capacity, in contrast to the Langmuir mode ${ }^{16}$. All data shown are the mean values of three replicate experiments, and error bars are indicated wherever necessary.

\section{RESULTS AND DISCUSSION}

\section{Characteristics of biosorbents}

In this study the bacterial strains of Stenotrophomonas maltophilia and Bacillus subtilis were identified according to Bergey's Manual of Systematic Bacteriology ${ }^{18}$. Their biochemical and microscopic characteristics are given in Table 1. B. subtilis is a gram-positive aerobic rod-shaped bacterium ubiquitous in soils and waters, with a well-known parietal structure ${ }^{\mathbf{1 9}}$. S. maltophilia is common in water and soil environments; many reports have indicated its potential wide application in biotechnology, including the biological control of plant pathogens, bioremediation and biosorption ${ }^{20}$.

\section{Effect of $\mathrm{pH}$}

The effect of hydrogen ion concentrations on the biosorption of heavy metals has been the subject of many studies, which shows the importance of this parameter on the solubility of the metal ions as well as on the ionization of the fixing sites ${ }^{5,17,21}$. In this work, $\mathrm{pH}$ was varied in order to determine its optimum value for maximum biosorption of lead, zinc and nickel ions. It can be seen from Figure 1 and Figure 2 that the biosorptive capacity of $\mathrm{Pb}(\mathrm{II}), \mathrm{Zn}(\mathrm{II})$ and $\mathrm{Ni}(\mathrm{II})$ by the two bacterial strains was very low at a low $\mathrm{pH}$ value and it increased with $\mathrm{pH}$ until reaching an optimum between 5.0 and 6.0. At levels higher than 6.0 the heavy metals begin to precipitate. $S$. maltophilia demonstrated a maximum capacity $\left(q_{e}\right)$ of $71.4 \mathrm{mg} / \mathrm{g}$ for $\mathrm{Pb}$ (II) and $29.8 \mathrm{mg} / \mathrm{g}$ for $\mathrm{Zn}$ (II) at $\mathrm{pH}$ 5.0 while $B$. subtilis demonstrated 78.8 and $30.0 \mathrm{mg} / \mathrm{g}$ respectively. The maximum biosorption of $\mathrm{Ni}(\mathrm{II})$ by $S$. maltophilia was $39.8 \mathrm{mg} / \mathrm{g}$ at $\mathrm{pH} 6.0$, and $40.1 \mathrm{mg} / \mathrm{g}$ for $B$. 
subtilis. At low $\mathrm{pH}$ values, cell wall ligands were closely associated with hydronium ions $\mathrm{H}_{3} \mathrm{O}^{+}$and so restricted the biosorption of $\mathrm{Pb}(\mathrm{II}), \mathrm{Zn}(\mathrm{II})$ and $\mathrm{Ni}(\mathrm{II})$ as a result of the competition between $\mathrm{H}_{3} \mathrm{O}^{+}$and the heavy metals with the bacterial biosorbent cell wall ligands ${ }^{22}$.

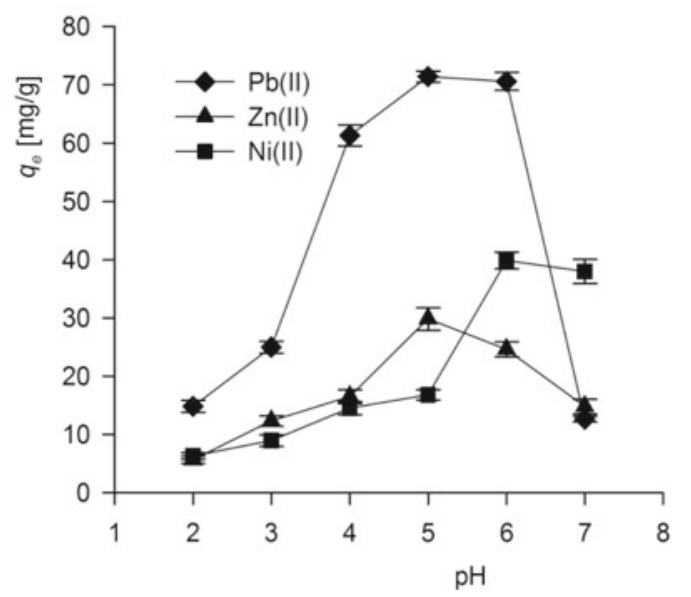

Figure 1. Effect of $\mathrm{pH}$ on the biosorption of $\mathrm{Pb}(\mathrm{II}), \mathrm{Zn}(\mathrm{II})$ and $\mathrm{Ni}(\mathrm{II})$ by Stenotrophomonas maltophilia. Metal concentration: $\mathrm{Pb}$ (II) $98.4 \mathrm{mg} / \mathrm{l}, \mathrm{Zn}$ (II) $39.6 \mathrm{mg} / \mathrm{l}$, $\mathrm{Ni}(\mathrm{II}) 45.6 \mathrm{mg} / \mathrm{l}$, contact time $30 \mathrm{~min}$

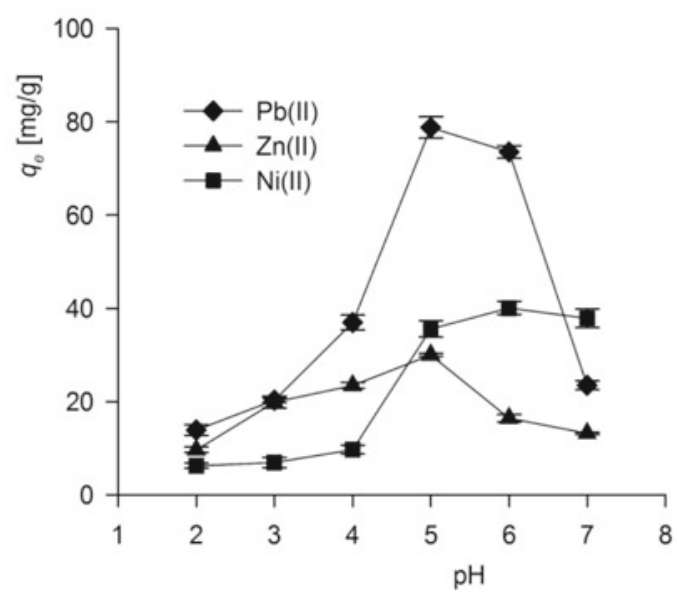

Figure 2. Effect of $\mathrm{pH}$ on the biosorption of $\mathrm{Pb}(\mathrm{II}), \mathrm{Zn}(\mathrm{II})$ and $\mathrm{Ni}(\mathrm{II})$ by Bacillus subtilis. Metal concentration: $\mathrm{Pb}$ (II) 98.4 mg/l, Zn(II) 39.6 mg/l, Ni(II) 45.6 mg/l, contact time $30 \mathrm{~min}$

Differences between the analyzed bacterial strains in their ability to bind metal ions are small. The higher metal binding capacity of B. subtilis (gram-positive) compared to $S$. maltophilia (gram-negative) can be traced back to the cell wall makeup. The gram-positive cell wall features a layer about 20-30 nm thick of peptidoglycan (PG) into which teichoic acids (TA) and teichuronic acids (TUA) are embedded. Peptidoglycan is a linear polymer of alternating glucosamine and muramic acid with peptide side chains. These side chains bear one carboxyl group at the terminal amino acid, and additional functional groups on certain intermediate amino acids like asparagine, lysine, cysteine, or aspartic acid. Teichoic acid contains phosphodiesters. Teichuronic acids feature carboxyl groups both of which contribute to the negative charge of the biomass and enable ion exchange. Gram-negative bacteria have a much thinner (only 1-3 molecules thick) PG layer which makes up about $10 \%$ of the weight of the total cell wall, which can be 30-80 nm thick. The PG layer of gram-negative bacteria does not contain TA or TUA, therefore they offer less negatively charged carboxyl groups, which is a reason for their lower biosorptive capacity ${ }^{23}$. On the other hand, a characteristic of these bacteria is an outer membrane which contains lipopolysaccharides (LPS) and phospholipids. Their phosphonate groups create a negative surface charge conducive to cation binding. As the $\mathrm{pH}$ increases, the competing effect of $\mathrm{H}_{3} \mathrm{O}^{+}$ions decreases. More functional groups such as carboxylic, phosphate and amino acid groups carrying negative charges are exposed ${ }^{\mathbf{1 7}, \mathbf{2 4}}$. The degree of ionization of these negative groups also increases; leading to electrostatic attractions between the positively charged cations such as $\mathrm{Pb}(\mathrm{II}), \mathrm{Zn}(\mathrm{II})$ and $\mathrm{Ni}(\mathrm{II})$ and the negatively charged binding sites, thereby promoting the binding of heavy metals ${ }^{\mathbf{9}, 25}$. This suggested that the biosorption of metals from wastewater is based on ion exchange. This finding also indicated that $\mathrm{Pb}(\mathrm{II}), \mathrm{Zn}(\mathrm{II})$ and $\mathrm{Ni}(\mathrm{II})$ removed was mainly bound to the cell walls and external surfaces of the biomass. Lead biosorption was maximal at $\mathrm{pH} 5.0$, a value in agreement with results obtained by Veglió et al. ${ }^{26}$ who found the maximal $\mathrm{pH}$ for lead by Arthrobacter sp. was 5.0. Çabuk et al. ${ }^{27}$ also reported the was $\mathrm{pH}=5.0$ to be optimal for the biosorption of $\mathrm{Pb}(\mathrm{II})$ by Bacillus sp. ATS-2. Similar results were observed by Sassi et al. ${ }^{5}$, Bahadir et al. ${ }^{4}$ and $\mathrm{Ho}^{28}$, while Çolak et al. ${ }^{29}$ concluded that the optimum $\mathrm{pH}$ for $\mathrm{Pb}(\mathrm{II})$ biosorption was 6.0 for Bacillus strains, and Rodríguez-Tirado et al. ${ }^{7}$ observed an optimum pH of 4.0 for Bacillus thioparans U3.

Maximal $\mathrm{pH}$ for zinc biosorption for the presented two bacterial species was 5.0. This is in agreement with Li et al. ${ }^{30}$ and Chen et al. ${ }^{\mathbf{1 6}}$, who also reported the optimum $\mathrm{pH}$ for $\mathrm{Zn}(\mathrm{II})$ removal by Pseudomonas putida CZ1 was 5.0. Other studies like Joo et al. ${ }^{17}$ and Aston et al. ${ }^{31}$ reported that maximal $\mathrm{pH}$ for zinc biosorption for Pseudomonas aeruginosa and Acidithiobacillus caldus BC13 were 6.0 and 4.0, respectively.

The maximal $\mathrm{pH}$ for $\mathrm{Ni}(\mathrm{II})$ biosorption for the presented bacterial biomass was 6.0. Pahlavanzadeh et al. ${ }^{\mathbf{1 0}}$ and Liu et al. ${ }^{22}$ reported maximal removal of nickel in the $\mathrm{pH}$ range 5.0-6.0. In contrast, Gabr et al. ${ }^{15}$ and Lopez et al. ${ }^{32}$ found the maximal $\mathrm{pH}$ for nickel biosorption for Pseudomonas aeruginosa ASU 6a and P. fluorescens 4F39 were 7.0 and 8.0, respectively. A decrease in the removal of $\mathrm{Ni}(\mathrm{II})$ at a $\mathrm{pH}$ above 6.0 is due to the formation of $\mathrm{Ni}(\mathrm{OH})_{2}$. Substantial precipitation of nickel and nickel hydroxide occurs at high $\mathrm{pH}$ values. The formation of hydroxide precipitate reduces the amount of free nickel ions ${ }^{\mathbf{1 3}}$.

\section{Effect of contact duration}

The kinetics of metal ion sorption is an important parameter for designing sorption systems and is required for selecting the optimum operating conditions for fullscale batch metal removal process ${ }^{22}$. The effect of contact duration on the extent of biosorption of $\mathrm{Pb}(\mathrm{II}), \mathrm{Zn}$ (II) and $\mathrm{Ni}$ (II) by bacterial biomass is shown in Figure 3 and 
Figure 4. The rate of $\mathrm{Pb}(\mathrm{II})$ biosorption by $S$. maltophilia and $B$. subtilis was very rapid, reaching almost $72.5 \%$ and $74.3 \%$ of the maximum adsorption capacity within 5 min of contact, respectively. However, it took longer for $\mathrm{Zn}(\mathrm{II})$ and $\mathrm{Ni}(\mathrm{II})$ to be adsorbed by S. maltophilia and $B$. subtilis, which reached approximate $67.4-73.5 \%$ and $63.9-78.9 \%$ of the maximum biosorption capacity within $20 \mathrm{~min}$, respectively. The initial fast uptake was likely due to the high initial $\mathrm{Pb}$ (II), $\mathrm{Zn}$ (II) and $\mathrm{Ni}(\mathrm{II})$ concentration and empty metal binding sites on the microbes. The slower subsequent phase was likely due to the saturation of metal binding sites. Therefore, one can conclude that the appropriate equilibrium time for measurements was reached at $30 \mathrm{~min}$. This represents the equilibrium time at which an equilibrium metal ion concentration is presumed to have been attained. This short time required for biosorption is in accordance with the results given by other authors ${ }^{\mathbf{1 0}}, \mathbf{1 5 - 1 7}, \mathbf{2 1}, \mathbf{3 0}$. Gabr et al. ${ }^{15}$, Joo et al. ${ }^{17}$ and Pahlavanzadeh et al. ${ }^{10}$ showed that the maximum biosorption of lead, zinc and nickel was reached after $30-40 \mathrm{~min}$. A rapid metal sorption is also highly desirable for successful deployment of biosorbents for practical applications ${ }^{16}$.

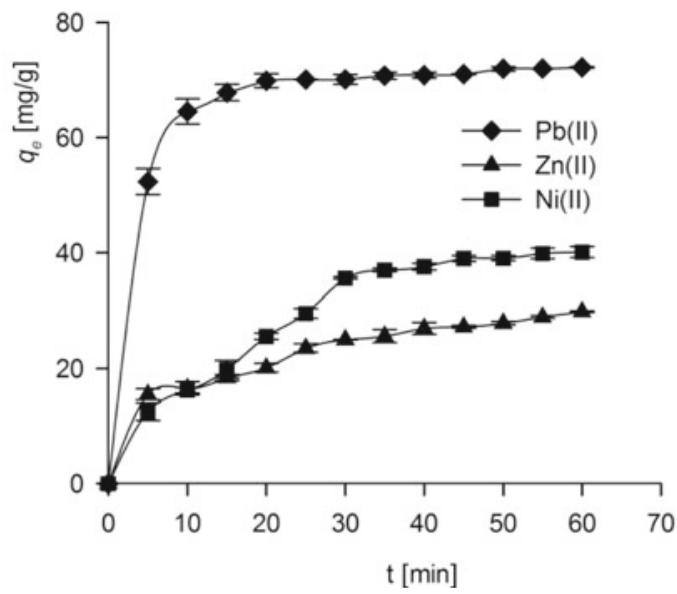

Figure 3. Effect of contact time on the biosorption of $\mathrm{Pb}(\mathrm{II})$, $\mathrm{Zn}(\mathrm{II})$ and Ni(II) by Stenotrophomonas maltophilia. Metal concentration: $\mathrm{Pb}$ (II) 98,4 mg/l, Zn(II) 39,6 $\mathrm{mg} / \mathrm{l}, \mathrm{Ni}(\mathrm{II})$ 45,6 mg/l, $\mathrm{pH} 5.5$

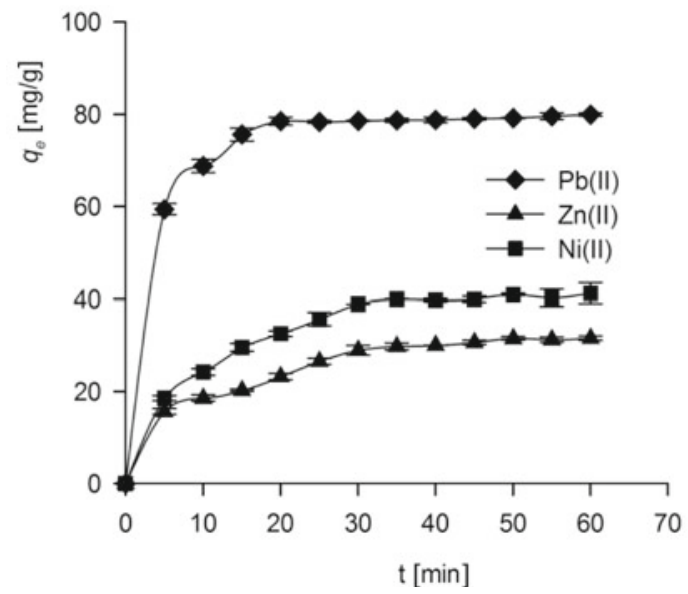

Figure 4. Effect of contact time on the biosorption of $\mathrm{Pb}(\mathrm{II})$, $\mathrm{Zn}(\mathrm{II})$ and $\mathrm{Ni}(\mathrm{II})$ by Bacillus subtilis. Metal concentration: $\mathrm{Pb}(\mathrm{II})$ 98,4 mg/l, $\mathrm{Zn}$ (II) 39,6 mg/l, Ni(II) $45,6 \mathrm{mg} / \mathrm{l}, \mathrm{pH} 5.5$

\section{Biosorption isotherm}

The biosorption isotherm curve represents the equilibrium distribution of metal ions between the aqueous and solid phases. The equilibrium distribution is important in determining the maximum biosorption capacity. Several isotherm models are available to describe this equilibrium distribution. Langmuir and Freundlich models are widely applied in equilibrium analysis to understand sorption mechanisms 9, 15-17, 21. The Langmuir model considers sorption by monolayer type and supposes that all the active sites on the sorbent surface have the same affinity for heavy metal ions ${ }^{33}$. The Freundlich isotherm is an empirical equation which assumes a heterogeneous biosorption system with different active sites ${ }^{30}$. The linearized Langmuir adsorption isotherms of each metal for $S$. maltophilia and B. subtilis are shown in Figures 5 and 6.

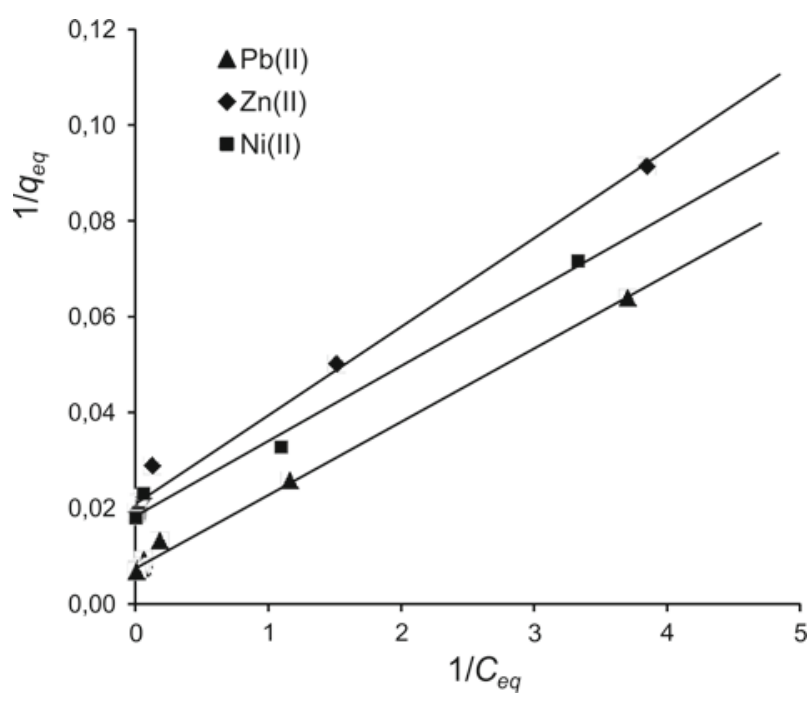

Figure 5. The linear from of Langmiur adsorption isotherm of $\mathrm{Pb}(\mathrm{II}), \mathrm{Zn}(\mathrm{II})$ and $\mathrm{Ni}(\mathrm{II})$ by Stenotrophomonas maltophilia. Metal concentration: $\mathrm{Pb}$ (II) 15.9-325.3 $\mathrm{mg} / \mathrm{l}, \mathrm{Zn}$ (II) $11.2-172.3 \mathrm{mg} / \mathrm{l}, \mathrm{Ni}(\mathrm{II}) 14.3-245.8 \mathrm{mg} / \mathrm{l}$, contact time 30 min., pH 5.5

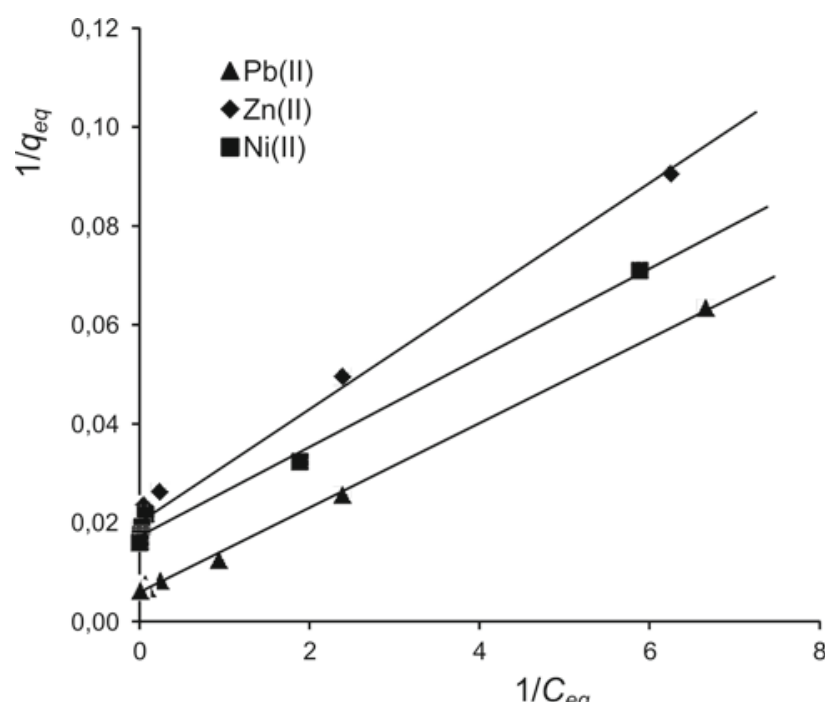

Figure 6. The linear from of Langmiur adsorption isotherm of $\mathrm{Pb}(\mathrm{II}), \mathrm{Zn}(\mathrm{II})$ and $\mathrm{Ni}(\mathrm{II})$ by Bacillus subtilis. Metal concentration: $\mathrm{Pb}(\mathrm{II})$ 15.9-325.3 mg/l, Zn(II) $11.2-172.3 \mathrm{mg} / \mathrm{l}, \mathrm{Ni}(\mathrm{II}) 14.3-245.8 \mathrm{mg} / \mathrm{l}$, contact time 30 min., pH 5.5 
The values of $q_{\max }, b$ and $R^{2}$ are given in Table 4 . High coefficients of determination $\left(R^{2}=0.990-0.998\right)$ for the Langmuir isotherm were obtained for all heavy metal biosorption with the bacterial isolates. A good fit of the Langmuir model indicates that the biosorption of $\mathrm{Pb}(\mathrm{II}), \mathrm{Zn}(\mathrm{II})$ and $\mathrm{Ni}(\mathrm{II})$ could be characterized by a monolayer formation of metal ions on the surface of the biomass and belongs to a single type phenomenon with no interactions between sorbed metals. This result was consistent with a number of earlier studies focusing on the adsorption of lead, zinc and nickel ions ${ }^{15,16,27,34}$. The Langmuir $q_{\max }$ represents the saturation level of sorbed metal ions at high solution concentrations ${ }^{30}$. In the experiment of $\mathrm{Pb}$ (II) and $\mathrm{Zn}$ (II) biosorption, the $q_{\max }$ values for $S$. maltophilia were respectively $133.3 \mathrm{mg} / \mathrm{g}$ and $47.8 \mathrm{mg} / \mathrm{g}$, compared to $166.7 \mathrm{mg} / \mathrm{g}$ and $49.7 \mathrm{mg} / \mathrm{g}$ for $B$. subtilis. It was also found that the value of $\mathrm{Ni}(\mathrm{II})$ biosorption by $B$. subtilis was higher $(57.8 \mathrm{mg} / \mathrm{g})$ than that of $S$. maltophilia $(54.3 \mathrm{mg} / \mathrm{g})$. The data show that at a high concentration of metal ions in wastewater the B. subtilis biomass showed a higher level of saturation with $\mathrm{Pb}$ (II), Zn (II) and Ni (II) than S. maltophilia.

It is known that $b$ is the constant related to the affinity of the binding sites, which allows us to make a comparison of the affinity of the biomass for metal ions. As shown in Table 4 the affinity of $B$. subtilis to $\mathrm{Pb}$ (II) and $\mathrm{Ni}(\mathrm{II})$ (0.019 and $0.047 \mathrm{l} / \mathrm{mg}$, respectively) was higher than that of S. maltophilia (0.016 and $0.036 \mathrm{1} / \mathrm{mg}$, respectively). However, the values obtained for $\mathrm{Zn}(\mathrm{II})$ indicate that S. maltophilia possesses a higher adsorption affinity for $\mathrm{Zn}(\mathrm{II})$ as compared to $B$. subtilis. As reported by Li et $\mathrm{al}^{30}$, the parameter indicates the shape of the isotherm and nature of the biosorption proces $\left(R_{L}>1\right.$ unfavorable; $R_{L}=1$ linear; $0<R_{L}<1$ favorable; $R_{L}=0$ irreversible). The values shown in Table 4 indicate that the use of $B$. subtilis biomass was more favorable for the biosorption of $\mathrm{Pb}$ (II) and $\mathrm{Ni}$ (II), while S. maltophilia was more useful for the biosorption of $\mathrm{Zn}$ (II).

The Freundlich isotherm equation was originally empirical in nature, but it was later interpreted to be used in the case of sorption on heterogeneous surfaces or surfaces supporting sites of different affinities. The linear plots of $\ln q_{e q}$ versus for the two isolates are displayed in Figures 7 and 8.

The values of $K_{f}, n$ and $R^{2}$ are shown in Table 4. The Freundlich isotherm represents the amount of metals sorbed when the solution concentration in the equilibrium is unity ${ }^{9,15,30}$. In Table 4, the magnitude of $K_{f}$ shows a higher uptake of $\mathrm{Pb}(\mathrm{II}), \mathrm{Zn}(\mathrm{II})$ and $\mathrm{Ni}(\mathrm{II})$ using $B$. subtilis compared to $S$. maltophilia. The values of $K_{f}$ were found to be 52.5, 21.3 and $26.0 \mathrm{l} / \mathrm{mg}$ biomass $B$. subtilis for $\mathrm{Pb}(\mathrm{II})$, $\mathrm{Zn}(\mathrm{II})$ and $\mathrm{Ni}(\mathrm{II})$ sorption and 36.4, 19.0, $23.6 \mathrm{l} / \mathrm{mg}$ for

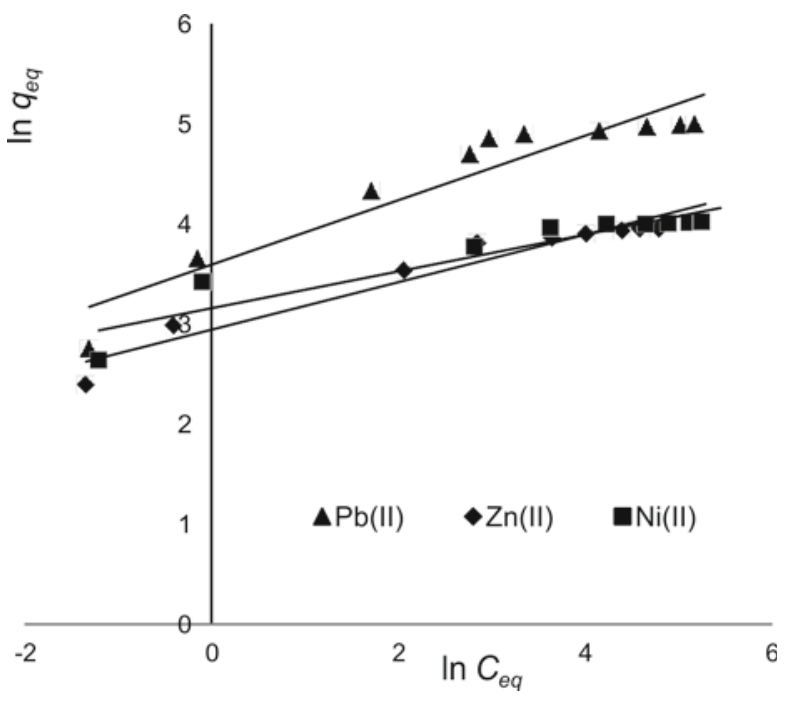

Figure 7. The linear from of the Freudlich adsorption isotherm of $\mathrm{Pb}(\mathrm{II}), \mathrm{Zn}(\mathrm{II})$ and $\mathrm{Ni}(\mathrm{II})$ by Stenotrophomonas maltophilia. Metal concentration: $\mathrm{Pb}$ (II) 15.9-325.3 $\mathrm{mg} / \mathrm{l}, \mathrm{Zn}$ (II) $11.2-172.3 \mathrm{mg} / \mathrm{l}, \mathrm{Ni}(\mathrm{II}) 14.3-245.8 \mathrm{mg} / \mathrm{l}$, contact time $30 \mathrm{~min}, \mathrm{pH} 5.5$

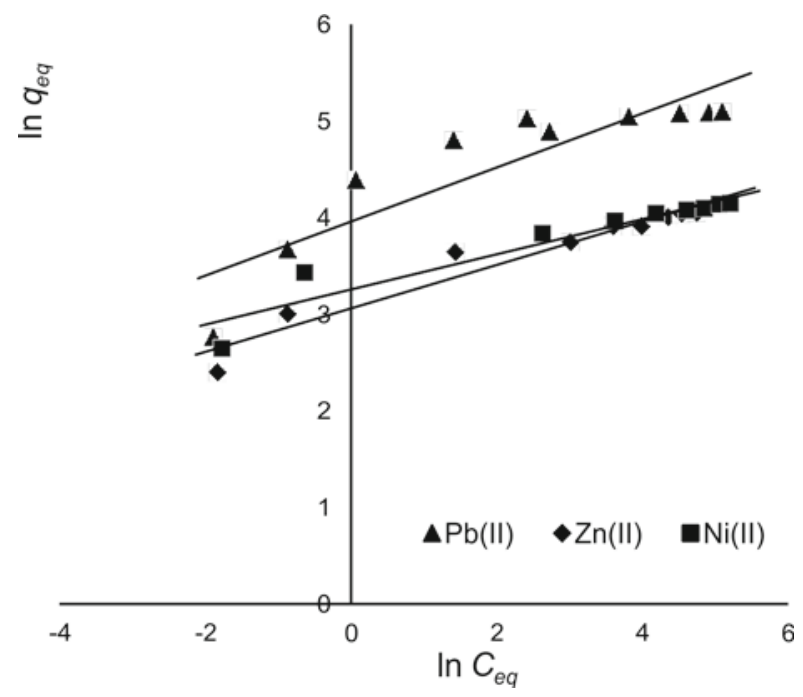

Figure 8. The linear from of the Freudlich adsorption isotherm of $\mathrm{Pb}(\mathrm{II}), \mathrm{Zn}(\mathrm{II})$ and $\mathrm{Ni}(\mathrm{II})$ by Bacillus subtilis. Metal concentration: $\mathrm{Pb}$ (II) 15.9 -325.3 mg/l, Zn(II) $11.2-172.3 \mathrm{mg} / \mathrm{l}, \mathrm{Ni}(\mathrm{II}) \mathbf{1 4 . 3}-245.8 \mathrm{mg} / \mathrm{l}$, contact time 30 min., pH 5

S. maltophilia, respectively. The results suggest that $B$. subtilis cells were characterized by higher biosorption than S. maltophili, even at low concentrations of metal ions in the wastewater. Çolak et al. ${ }^{29}$ showed that the value of obtained for lead sorption by $B$. cereus and $B$. pumilus were 30.78 and $39.40 \mathrm{l} / \mathrm{mg}$ biomass. Likewise, lead and nickel ions sorption by $P$. aerugionas ASU 6a gave 40.04 and $24.14 \mathrm{l} / \mathrm{mg}$ biomass, respectively ${ }^{15}$. A value of

Table 4. Langmuir and Freundlich parameters fo the biosorption of $\mathrm{Pb}(\mathrm{II}), \mathrm{NI}(\mathrm{II})$ and $\mathrm{Zn}(\mathrm{II})$ by S. maltophilia and B. subtilis

\begin{tabular}{|l|l|c|c|c|c|c|c|c|}
\hline \multirow{2}{*}{ Metals } & \multirow{2}{*}{ Biosorbent } & \multicolumn{3}{|c|}{ Langmuir isotherm } & \multicolumn{3}{c|}{ Freundlich isotherm } \\
\cline { 2 - 8 } & & $q_{\max }[\mathrm{mg} / \mathrm{g}]$ & $b[\mathrm{l} / \mathrm{mg}]$ & $R^{2}$ & $R_{L}$ & $K_{f}[\mathrm{l} / \mathrm{mg}]$ & $n$ & $R^{2}$ \\
\hline \multirow{2}{*}{$\mathrm{Pb}(\mathrm{II})$} & Stenotrophomonas maltophilia & 133.3 & 0.016 & 0.996 & 0.16 & 36.4 & 3.91 & 0.891 \\
\cline { 2 - 8 } & Bacillus subtilis & 166.7 & 0.019 & 0.998 & 0.14 & 52.5 & 4.81 & 0,789 \\
\hline \multirow{2}{*}{$\mathrm{Zn}(\mathrm{II})$} & Stenotrophomonas maltophilia & 47.8 & 0.057 & 0.990 & 0.09 & 19.0 & 4.06 & 0.937 \\
\cline { 2 - 9 } & Bacillus subtilis & 49.7 & 0.044 & 0.990 & 0.11 & 21.3 & 3.61 & 0.938 \\
\hline \multirow{2}{*}{$\mathrm{Ni}(\mathrm{II})$} & Stenotrophomonas maltophilia & 54.3 & 0.036 & 0.990 & 0.10 & 23.6 & 5.38 & 0.873 \\
\cline { 2 - 9 } & Bacillus subtilis & 57.8 & 0.047 & 0.990 & 0.08 & 26,0 & 5.71 & 0.903 \\
\hline
\end{tabular}


$n$ which is related to the distribution of bonded ions on the sorbent surface, represents beneficial adsorption ${ }^{35}$. Larger values of $n$ imply stronger interactions between the biosorbent and the heavy metals ${ }^{30}$. In this study, the $n$ values for $B$. subtilis were 3.61-5.71 while those for $S$. maltophilia were 3.91-5.38, from which it could be derived that the effect of lead and nickel ions on B. subtilis was stronger than that on $S$. maltophilia biomass. Values of the correlation coefficient $\left(R^{2}=0.789-0.938\right)$ are lower than the Langmuir model in the studied concentration range. Generally it can be stated that the sorption of lead, zinc and nickel by the analyzed bacterial strains depended on the initial concentration of the metal ions in wastewater. B. subtilis had high $K_{f}$ and $q_{\max }$ values, indicating high sorption capacity, especially with regard to $\mathrm{Pb}(\mathrm{II})$, over the entire range of heavy metal ion concentrations in wastewater. The values obtained for $S$. maltophilia suggest its potential usefulness for the removal of $\mathrm{Pb}(\mathrm{II}), \mathrm{Zn}(\mathrm{II})$ and $\mathrm{Ni}(\mathrm{II})$ from wastewater containing low concentrations of these metals.

Figure 9 shows the efficiency of $S$. maltophilia and $B$. subtilis in removing of $\mathrm{Pb}(\mathrm{II}), \mathrm{Zn}(\mathrm{II})$ and $\mathrm{Ni}(\mathrm{II})$ from industrial wastewater (wastewater composition is shown in Table 2). Regardless of the type of used bacteria biomass, the efficiency of $\mathrm{Pb}(\mathrm{II}), \mathrm{Zn}(\mathrm{II})$ and $\mathrm{Ni}(\mathrm{II})$ removal was over $96 \%$ when the concentration in the wastewater did not exceed, 39.6, 20.6 and $31.5 \mathrm{mg} / \mathrm{l}$, respectively.

Efficiency decreased with the increase of metal concentration in the wastewater, especially with regard to zinc and nickel ions. Only for lead ions did it remain above $80 \%$, despite high concentrations of metals in the wastewater; $162.7,104.3$ and $159.4 \mathrm{mg} / \mathrm{l}$, respectively for $\mathrm{Pb}(\mathrm{II}), \mathrm{Zn}$ (II) and $\mathrm{Ni}$ (II). In raw wastewater, removal efficiency was less than $49 \%$ of lead ions, and less than
$33 \%$ zinc and $25 \%$ nickel ions. The differences in the results obtained after the application of S. maltophilia and $B$. subtilis were around $10-12 \%$. The high affinity of living cells of genera Pseudomonas and Bacillus for $\mathrm{Pb}$ (II) is also confirmed in other studies by this author ${ }^{36}$.

The descending order of selectivity of metal ions by the biomasses was $\mathrm{Pb}>\mathrm{Zn}>\mathrm{Ni}$. This preferential type of adsorption may be ascribed to the difference in ionic radii and the electro-negativity of the metal ions. The ionic radius of $\mathrm{Pb}(\mathrm{II})$ is $1.20 \mathrm{~A}^{\mathrm{o}}$, while that of $\mathrm{Zn}$ (II) and $\mathrm{Ni}(\mathrm{II})$ is $0.9 \mathrm{~A}^{\mathrm{o}}$. The smaller the ionic radius, the greater its tendency to be hydrolyzed, leading to reduced biosorption. The electro-negativity of $\mathrm{Pb}$ (II) (2.33 Pauling) is greater than that of $\mathrm{Ni}(\mathrm{II})$ (1.91 Pauling) and $\mathrm{Zn}$ (II) (1.60 Pauling). Both the aforementioned factors contributed to the bacterial biomass had a greater affinity for lead than for nickel or zinc ${ }^{36}$. A comparison between the results of this work for S. maltophilia and B. subtilis and other studies found in literature is presented in Table 5. Thus, the comparison of adsorption capacities shows that the studies species of bacteria were efficient biosorbents of $\mathrm{Pb}(\mathrm{II}), \mathrm{Ni}(\mathrm{II})$ and $\mathrm{Zn}(\mathrm{II})$.

\section{CONCLUSIONS}

In this study, the live bacterial biomasses of $S$. maltophilia and B. subtilis were used as effective biosorbents of $\mathrm{Pb}(\mathrm{II}), \mathrm{Zn}(\mathrm{II})$ and $\mathrm{Ni}(\mathrm{II})$ from wastewaters. The biosorption performances were strongly affected by parameters such as $\mathrm{pH}$, contact duration and heavy metal concentration. The optimum $\mathrm{pH}$ for the biosorption of $\mathrm{Pb}(\mathrm{II}), \mathrm{Zn}(\mathrm{II})$ and $\mathrm{Ni}(\mathrm{II})$ by the two bacterial species was achieved at $\mathrm{pH} 5.0-6.0$ for $30 \mathrm{~min}$. The uptake of metals was very fast. Adsorption equilibrium was reached

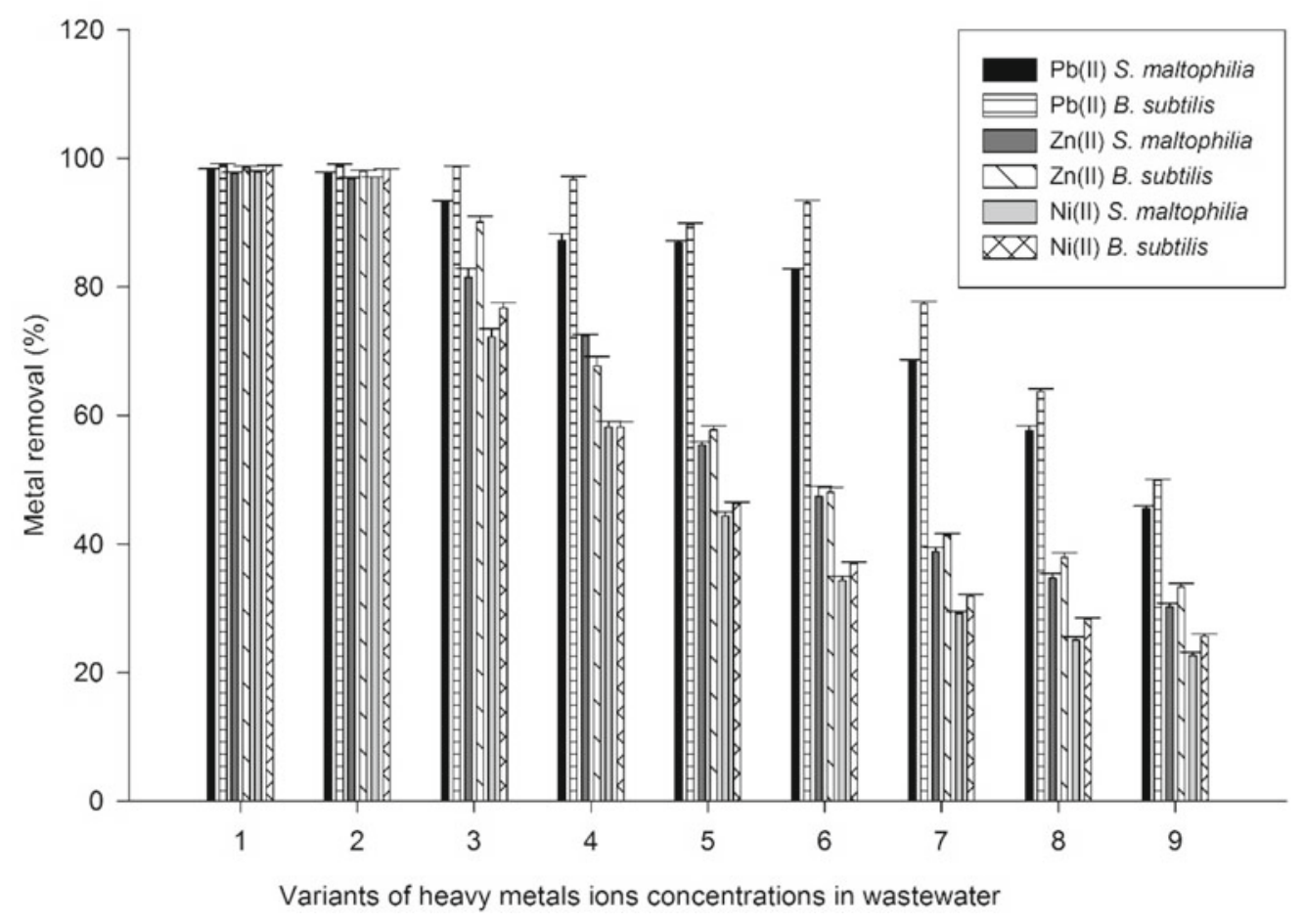

Figure 9. Comparison of metals removal from wastewater by $S$. maltophilia and B. subtilis. Variants concentrations of heavy metals ions in wastewater (mg/l): 1: $\mathrm{Pb}(\mathrm{II})-15.9, \mathrm{Zn}(\mathrm{II})-11.2, \mathrm{Ni}(\mathrm{II})-14.3 ; 2$ : $\mathrm{Pb}(\mathrm{II})-39.6, \mathrm{Zn}(\mathrm{II})-20.6, \mathrm{Ni}(\mathrm{II})-31.5 ; 3$ : Pb(II)-81.5, Zn(II)-42.3, Ni(II)-60.2; 4: Pb(II)-125.4, Zn(II)-62.4, Ni(II)-90.2; 5: Pb(II)-147.8, Zn(II)-86.0, Ni(II)-123.6; 6: Pb(II)-162.7, Zn(II)-104.3, Ni(II)-159.4; 7: Pb(II)-201.3, Zn(II)-132.2, Ni(II)-188.6; 8: Pb(II)-250.6, Zn(II)-149.9, $\mathrm{Ni}(\mathrm{II})-221.4$; 9: $\mathrm{Pb}(\mathrm{II})-325.3, \mathrm{Zn}(\mathrm{II})-172.3$, Ni(II)-245.8 
Table 5. Comparison of other biosorbents from selected literature with the present work

\begin{tabular}{|c|c|c|c|c|}
\hline Metal ion & Biororbent & $\mathrm{pH}$ & $\mathrm{q}_{\max }[\mathrm{mg} / \mathrm{g}]$ & Reference \\
\hline \multirow{8}{*}{ Lead } & B. subtilis & 5.0 & 166.7 & This work \\
\hline & S. maltophilia & 5.0 & 133.3 & This work \\
\hline & P. aeruginosa ASU $6 a$ & 6.0 & 123.0 & Gabr et al. ${ }^{15}$ \\
\hline & Rhodococcus oparus & 5.0 & 95.2 & Bueno et al. ${ }^{37}$ \\
\hline & B. cereus & 6.0 & 23.2 & Çolak et al. ${ }^{29}$ \\
\hline & B. pumilus & 6.0 & 29.6 & Çolak et al. ${ }^{29}$ \\
\hline & Dairy sludge & 5.0 & 148.6 & Sassi et al. ${ }^{5}$ \\
\hline & Granular sludge & 5,0 & 286.0 & Hawari et al. $^{33}$ \\
\hline \multirow{6}{*}{ Zinc } & B. subtilis & 5.0 & 49.7 & This work \\
\hline & S. maltophilia & 5.0 & 47.8 & This work \\
\hline & Bacillus jeotgali U3 & 7.0 & 128.2 & Green-Ruiz et al. $^{35}$ \\
\hline & Pseudomonas putida CZ1 & 5.0 & 27.4 & Chen et al. ${ }^{16}$ \\
\hline & $P$. aeruginosa ASU $6 a$ & 6.0 & 83.3 & Joo et al. ${ }^{17}$ \\
\hline & B. cereus AUMC B52 & 6.0 & 66.6 & Joo et al. ${ }^{17}$ \\
\hline \multirow{6}{*}{ Nickel } & B. subtilis & 6.0 & 58.7 & This work \\
\hline & S. maltophilia & 6.0 & 54.3 & This work \\
\hline & Bacillus sp. & 7.0 & 244.0 & Zaidi and Musarrat $^{34}$ \\
\hline & Yarrowia lipolytica NCIM 3589 & 7.5 & 138.9 & Shinde et al. ${ }^{38}$ \\
\hline & $P$. aeruginosa ASU $6 a$ & 7.0 & 113.6 & Gabr et al. ${ }^{15}$ \\
\hline & Granular sludge & 5,0 & 25.0 & Hawari et al. ${ }^{33}$ \\
\hline
\end{tabular}

within 30 min of biomass addition. The applied biomass had a high affinity for $\mathrm{Pb}(\mathrm{II})$, and then $\mathrm{Zn}(\mathrm{II})$ and $\mathrm{Ni}(\mathrm{II})$.

The batch experimental results fitted well to the Langmuir isotherm model. The maximum adsorption uptake $\left(q_{\max }\right)$ of respectively $\mathrm{Pb}(\mathrm{II}), \mathrm{Zn}(\mathrm{II})$ and $\mathrm{Ni}(\mathrm{II})$ calculated from the Langmuir equation for biosorption by $S$. maltophilia and B. subtilis were $133.3,47.8$ and 54.3 and $166.7,49.7$ and $57.8 \mathrm{mg} / \mathrm{g}$. Efficiency of removing metal ions from wastewater decreased with their increasing concentration. Only in the case of $\mathrm{Pb}(\mathrm{II})$ did it not decrease below $80 \%$, even when the concentration of $\mathrm{Pb}(\mathrm{II}), \mathrm{Zn}(\mathrm{II})$ and $\mathrm{Ni}(\mathrm{II})$ were $162.7,104.3$ and 159.4 $\mathrm{mg} / \mathrm{l}$ respectively. The results of the experiments show the possibility of using $B$. subtilis and $S$. maltophilia as sorbents of $\mathrm{Pb}(\mathrm{II}), \mathrm{Zn}(\mathrm{II})$ and $\mathrm{Ni}(\mathrm{II})$ from wastewater.

\section{LITERATURE CITED}

1. Lesmana, S.O., Febriana, N., Soetaredjo, F.E., Sunarso, J. \& Ismadji, S. (2009). Studies on potential applications of biomass for the separation of heavy metals from water and wastewater. Biochem. Eng. J. 44, 19-41. DOI: 10.1016/j.bej.2008.12.009.

2. Nourbakhsh, M.N., Kiliçarslam, S., Ilhan, S. \& Ozdag, H. (2002). Biosorption of $\mathrm{Cr}^{6+}, \mathrm{Pb}^{2+}$ and $\mathrm{Cu}^{2+}$ ions In industrial waste water on Bacillus sp. Chem. Eng. J. 85, 351-355. DOI: 10.1016/S1385-8947(01)00227-3.

3. Choi, A., Wang, S. \& Lee, M. (2009). Biosorption of cadmium, copper, and lead ions from aqueous solution by Ralstonia sp. and Bacillus sp. isolated from diesel and heavy metal contaminated soil. Geosci. J. 13(4), 331-341. DOI: 10.1007/s12303-009-0031-3.

4. Bahadir, T., Bakan, G., Altas, L. \& Buyukgungor, H. (2007). The investigation of lead removal by biosorption: An application AT storage battery industry wastewaters. Enzyme. Microb. Tech. 41, 98-102. DOI: 10.1016/j.enzmictec.2006.12.007. 5. Sassi, M., Bestani, B., Said, A.H., Benderdouche, N. \& Guibal, E. (2010). Removal of heavy metal ions from aqueous solutions by a local dairy sludge as a biosorbant. Desalination. 262, 243-250. DOI: 10.1016/j.desal.2010.06.022.

6. Muñoz, A.J., Ruiz, E., Abriouel, H., Gálvez, A., Ezzouhri, L., Lairini, K. \& Espinola, F. (2012). Heavy metal tolerance of microorganisms isolated from wastewaters: Identification and evaluation of its potential for biosorption. Chem. Eng. J. 210, 325-332. DOI: 10.1016/J.cej.2012.09.007.

7. Rodriguez-Tirado, V., Green-Ruiz, C. \& Gómez-Gil, B. (2012). $\mathrm{Cu}$ and $\mathrm{Pb}$ biosorption on Bacillus thioparans strain U3 in aqueous solution: Kinetic and equilibrium studies. Chem. Eng. J. 181-182, 352-359. DOI: 10.1016/j.cej.2011.11.091.

8. Ahluwalia, S.S. \& Goyal, D. (2007). Microbial and plant derived biomass for removal of heavy metals from wastewater. Bioresource Technol. 98, 2243-2257. DOI: 10.1016/j. biortech.2005.12.006.

9. Shroff, K.A. \& Vaidya, V.K. (2011). Kinetic and equilibrium studies on biosorption of nickel from aqueous solution by dead fungal biomass of Mucor hiemalis. Chem. Eng. J. 171, 1234-1245. DOI: 10.1016/j/cej.2011.05.034.

10. Pahlavanzadeh, H., Keshtkar, A.R., Sfadari, J. \& Abadi, Z. (2010). Biosorption of nikel(II) from aqueous solution by Brown algae: Equilibrium, dynamic and thermodynamic studies. J. Hazard. Mater. 175, 304-310. DOI: 10.1016/j/jhazmat.2009.10.004. 11. Kratochvil, D. \& Volesky, B. (1998). Advances in the biosorption of heavy metals. Trends Biotechmol. 16, 291-300. DOI: 10.1016/S0167-7799(98)01218-9.

12. Vijayaraghavan, K. \& Yun, Y.S. (2008). Bacterial biosorbents and biosorption. Biotechnol. Adv. 26, 266-291. DOI: 10.1016/j.biotechadv.2008.02.002.

13. Congeevaram, S., Dhanarani, S., Park, J., Dexilin, M. \& Thamaraiselvi, K. (2007). Biosorption of chromium and nickel by heavy metal resistant fungal and bacterial isolates. J. Hazard. Mater. 146, 270-277. DOI: 10.1016/j.hazmat.2006.12.017. 14. Vegli, F., Beolchini, F. (1997). Removal of metals by biosorption: a review. Hydrometallurgy 44, 301-316. DOI: 10.1016/ S0304-386X(96)00059-X.

15. Gabr, R.M., Hassan, S.H.A. \& Shoreit, A.A.M. (2008). Biosorption of lead and nickel by living and non-living cells of Pseudomonas aeruginosa ASU 6a. Int. Biodeter. Biodegr. 62, 195-203. DOI: 10.1016/j.ibiod.2008.01.008.

16. Chen, C.X., Wang, P.Y., Lin, Q., Shi, Y.J., Wu, W.X. \& Chen, Y.X. (2005). Biosorption of copper(II) and zinc(II) from aqueous solution by Pseudomonas putida CZ1. Colloid. Surface. B. 46, 101-107. DOI: 10.1016/j.colsurfb.2005.10.00.

17. Joo, J.H., Hassan, S.H.A., Oh, S.E. (2010). Comparative study of biosorption of $\mathrm{Zn}^{2+}$ by Pseudomonas aeruginosa and Bacillus cereus. Int. Biodeter. Biodegr. 64, 734-741. DOI: 10.1016/j.biod.2010.08.007.

18. Sneath, P.H.A., Mair, N.S., Sharpe, M.E. \& Holt, J.G. (1986). Bergey's Manual of Systematic Bacteriology Vol. 2. Williams \& Wilkins, Baltimore. ISBN 978-0-387-95040-2.

19. Ji, Y., Gao, H., Sun, J. \& Cai, F. (2011). Experimental probation on the binding kinetics and termodynamics of AU(III) onto Bacillus subtilis. Chem. Engine. J., 172, 122-128. DOI: 10.1016/j.cej.2011.05.077.

20. Nawaz, M.S., Franklin, W. \& Cerniglia, C.E. (1993). Degradation of acrylamide by immobilized cells of a Pseudomonas 
sp. And Xanthomonas maltophilia. Can. J. Microbiol. 39(2), 207-212. DOI: 10.1111/j.1574-6968.2010.02085.x.

21. Ji, Y., Gao, H., Sun, J. \& Cai, F. (2011). Experimental probation on the binding kinetics and thermodynamics of $\mathrm{Au}(\mathrm{III})$ onto Bacillus subtilis. Chem. Eng. J. 172, 122-128. DOI: 10.1016/j.cej.2011.05.077.

22. Liu, Y., Cao, Q., Luo, F. \& Chen, J. (2009). Biosorption of $\mathrm{Cd}^{2+}, \mathrm{Cu}^{2+}, \mathrm{Ni}^{2+}$, and $\mathrm{Zn}^{2+}$ ions from aqueous solutions by pretreated biomass of brown algae. J. Hazard. Mater. 163, 931-938. DOI: 10.1016/j.hazmat.2008.07.046.

23. Wang, J. \& Chen, C. (2009). Biosorbents for heavy metals removal and their future. Biotech. Adv. 27, 195-226. DOI: 10.1016/j.biotechadv.2008.11.002.

24. Lopez, A., Lazaro, N., Priego, J.M. \& Marques, A.M. (2000). Effect of pH on the biosorption of nickel and other heavy metals by Pseudomonas fluorescens 4F39. J. Ind. Microbiol. Biot. 24, 146-151. DOI: 10.1038/sj.jim.2900793.

25. Fosso-Kankeu, E., Mulaba-Bafubiandi, A.F., Mamba, B.B., Marjanovic, L. \& Barnard, T.G. (2010). A comprehensive study of physical and physiological parameters that affect biosorption of metal pollutants from aqueous solutions. Phys. Chem. Earth. 35, 672-678. DOI: 10.1016/j.pce.2010.07.008.

26. Veglió, F., Beolchini, F. \& Gasbarro, A. (1997). Biosorption of toxic metals: an equilibrium study using free cells of Arthrobacter sp. Process Biochem. 32, 99-105. DOI: 10.1016/ S0032-9592(96)00047-7.

27. Çabuk, A., Akar, T., Tunali, S. \& Tabak, O. (2006). Biosorption characteristic of Bacillus sp. ATS-2 immobilized in silica gel for removal of $\mathrm{Pb}(\mathrm{II})$. J. Hazard. Mater. 136, 317-323. DOI: 10.1016/j.hazmat.2005.12.019.

28. Ho, Y.S. (2005). Effect of $\mathrm{pH}$ on lead removal from water using tree fern as the sorbent. Bioresource Technol. 96, 1292-1296. DOI: 10.1016/j.biotech.2004.10.011.

29. Çolak, F., Atar, N., Yazicioğlu, D. \& Olgun, A. (2011). Biosorption of lead from aqueous solution by Bacillus strains possessing heavy-metal resistance. Chem. Eng. J. 173, 422-428. DOI: 10.1016/j.cej.2011.07.084.

30. Li, H., Lin, Y., Guan, W., Jiali, Ch., Xu, L., Gou, J. \& Wei, G. (2010). Biosorption of $\mathrm{Zn}$ (II) by live and dead cells of Streptomyces ciscaucasicus strain CCNWHX 72-14. J. Hazard. Mater. 179, 151-159. DOI: 10.1016/j.hazmat.2010.02.072. 31. Aston, J.E., Apel, W.A., Lee, B.D. \& Peyton, B.M. (2010). Effects of cell condition, $\mathrm{pH}$ and temperature on lead, zinc and copper sorption to Acidithiobacillus caldus strain BC13. J. Hazard. Mater. 184, 34-41. DOI: 10.1016/j.hazmat.2010.07.110. 32. Lopez, A., Lazaro, N., Morales, S. \& Marques, A.M. (2002). Nickel biosorption by free and immobilized cells of Pseudomonas fluorescens 4F39: a comparative study. Wat. Air Soil Poll. 135, 157-172. DOI: 10.1023/A:1014706827124.

33. Hawari, A.H. \& Mulligan, C.N. (2006). Biosorption of lead(II), cadmium(II), copper(II) and nickel(II) by anaerobic granular biomass. Bioresource Technol. 97, 692-700. DOI: 10.1016/j.biortech.2005.03.033.

34. Zaidi, S. \& Musarrat, J. (2004). Characterization and nickel sorption kinetics of a new metal hyper-accumulator Bacillus sp. J. Environ. Sci. Heal. A. 39(3), 681-691. DOI: 10.1081/ ESE-120027734.

35. Green-Riuz, C., Rodriguez-Tirado, V. \& Gomez-Gil, B. (2008). Cadmium and zinc removal from aqueus solution by Bacillus jeotgali: $\mathrm{pH}$, salinity and temperature effects. Bioresource Technol. 99, 3864-3870. DOI: 10.1016/j.biortech.2007.06.047.

36. Wierzba, S. \& Latała, A. (2010). Biosorption lead(II) and nickel(II) from an aqueous solution by bacterial biomass. Pol. J. Chem. Technol. 12(3), 72-78. DOI: 10.2478/v10026-010-0038-6. 37. Bueno, B.Y.M., Torem, M.L., Carvalho, R.J., Pino, G.A.H. \& Mesquita, L.M.S. (2011). Fundamental aspects of biosorption of lead (II) ions onto a Rhodococcus oparus strain for environmental applications. Miner. Eng. 24, 1619-1624. DOI: 10.1016/j.mineng.2011.08.018.
38. Shinde, N.R., Bankar, A.V., Kumar, A.R. \& Zinjarde, S.S. (2012). Removal of $\mathrm{Ni}(\mathrm{II})$ ions from aqueous solutions by biosorption onto two strains of Yarrowia lipolytica. J. Environ. Manage. 102, 115-124. DOI: 10.1016/j.envman.2012.02.026. 